Article

\title{
Spiritual Pathology: The Case of Adolf Hitler
}

\author{
W. George Scarlett
}

Eliot-Pearson Department of Child Development, Tufts University, Medford, MA 02155, USA;

E-Mail: george.scarlett@tufts.edu

Received: 27 March 2012; in revised form: 1 April 2012 / Accepted: 13 April 2012 /

Published: 26 April 2012

\begin{abstract}
Hitler had a noble purpose (to save the world) and a strong faith in the laws of Nature as he understood Nature. He was, then, a spiritual person, though his spirituality was pathological and destructive. Here, the example of Hitler, his faith, and his spiritual pathology is given to both understand spiritual pathology in general and, through contrast, to understand positive spiritual development.
\end{abstract}

Keywords: Hitler; spiritual pathology; pathological faith

\section{Introduction: Arrested vs. Pathological Spiritual Development}

On July $13^{\text {th }}$, 1942, just after dawn a group of German reservists were assembled outside the small Polish town of Jozefow. ${ }^{1}$ These were ordinary Germans who had avoided active, front-line military duty by volunteering for what they had expected would be police work in newly occupied territories such as Poland. These were not the carefully selected killers making up the Einsatzgruppen or special units of the SS selected for their fanaticism and extreme anti-Semitism. The reservists formed a motley crew with respect to anti-Semitism, but none of them were eager to kill Jews. They shared nationalist sentiments and pride in being German, but their main concern was for returning to their families as soon as possible. They were more than surprised, then, when their commander, Major Wilhelm Trapp, told them their assignment was to kill the Jewish women, children, and old people of the village-and to gather up the Jewish males of working age so they could be sent to work camps. Trapp gave his order haltingly, almost apologetically, and with the added message that men who did not feel up to the

1 This account and interpretation is drawn largely from that of Christopher Browning [1]. It contrasts sharply with the interpretation of Daniel Goldhagen [2] who explains the massacre at Jozefow in terms of "eliminationist" anti-semitism latent in ordinary Germans prior to the Second World War. 
task could refrain from doing so without consequences. The reservists, then, were not coerced to kill. Nevertheless, within hours after Trapp's order these ordinary men had not only killed; they had committed mass murder and extraordinary evil. Why?

Answers to this question have varied. Some answers have been attempts to demonize Germans or, at least, Germans prior to 1945 . However, the evidence suggests the atrocity at Jozefow and many other atrocities throughout history are not due to extraordinary personal and cultural traits but to ordinary forces operating within and outside people everywhere. Over and over again, cases of evil deeds, even extraordinary evil deeds, have been found to be deeds carried out by ordinary people who found themselves without an adequate moral compass to navigate in extraordinary circumstances. To guide their decision-making, the reservists called upon the lesser values of duty, consideration for comrades, and being manly. A few may have harbored the warped sense of justice concerning Jews that pervaded Nazi ideology, but for the most part, justice was not what was on their minds.

What lesson can we learn from this sad fact that extraordinary evil is often carried out by ordinary people? The main lesson seems to be that immature, weak, arrested spiritual development is the norm, not the exception. The spiritual development of the reservists may have been enough to guide them through ordinary domestic dilemmas and adversity, but it was nowhere near enough to help the reservists keep faith in core spiritual values during extraordinary times such as they faced at Jozefow. One implication of this lesson is, then, that even extraordinary evil acts are not adequate for measuring spiritual pathology - because such measuring does not distinguish the extraordinary from the ordinary.

With this realization, we may feel paralyzed when trying to judge what is and is not spiritual pathology. After all, if we cannot measure spiritual pathology by evil acts, how can we ever hope to measure it? And if we can't measure it, perhaps there are no distinctions to make with regard to spiritualities and pathology.

This view that there are no distinctions to be made between different spiritualities with respect to pathology might be plausible if it were not for the fact that most of us have direct or indirect experience with spiritual pathology - though we are not likely to have called it by that name. Furthermore, throughout history, evil acts have been carried out not only by ordinary people such as the reservists but also by fanatics whose faith is so terrible as to deserve to be called pathological and not simply weak or underdeveloped faith.

It is pathological faith, then, that we must identify and understand, and for this purpose, we can use the example of Adolf Hitler. Obviously, Hitler is an exceptional, even unique case, so exceptional and unique that one might question whether there is anything that can be generalized from it. The answer is there is quite a lot, for the case of Hitler teaches us much about spiritual pathology and its development.

\section{The Case of Adolf Hitler}

There are many, perhaps the majority, who would argue that there is nothing spiritual about Hitler, pathological or otherwise. In his book on gurus who attract fanatical followers, Anthony Storr omitted Hitler from his group of examples because he thought Hitler was not a spiritual teacher ([3], p. 219). Others have, somewhat paradoxically, excluded Hitler as an example by demonizing Hitler - as when Pope Pius XII referred to Hitler and National Socialism as a "satanic apparition"- thus removing Hitler and Nazism from the domain of human phenomena ([4], p. 265). A good many have reduced 
Hitler's religious talk and faith statements to being symptoms of underlying mental illness. Still others have spoken about Hitler's mind, his ideology, and his worldview, as if these substitute for what is here referred to as Hitler's faith. They do not.

But what exactly do we gain by ascribing spirituality and faith to Hitler? What do we gain over these other, non-spiritual approaches to Hitler? From a negative standpoint, we gain because these other attempts have failed to capture the Hitler phenomenon. This is not to say that ascribing faith and spirituality to Hitler fully explains Hitler. Hitler will never be fully explained. Rather, it is to say that there is something missing in these other accounts that a faith approach can supply. We have already indicated that what is missing in the demonizing approach is an understanding of Hitler as a historical and human phenomenon. What is missing in the psychopathology and ideological approaches requires more explanation.

That Hitler had psychological problems is clear. What is not clear is how we should define and explain those problems. Nor is it clear how much of Hitler's actions derive from his psychological problems. Hitler's actions have been given a variety of psychological explanations, including explanations in terms of the "poisonous pedagogy" of his father [5], the inadequate mothering he received in early childhood [6], his assuming the burden of his parents' marital problems [7], his being from a culture which failed to support healthy identity formation [8], and his repressing anger over the failure of his mother's Jewish doctor to save her life [9].These are just a few of the many efforts at psychological explanations of Hitler.

Collectively, these psychological explanations fail to adequately explain Hitler-either because the evidence is thin (e.g., Binion's argument) or because the problems being pointed to are so common that they do not bear the weight of Hitler's monstrous and unique career (e.g., Miller's argument). In short, they do not add up to explaining how it was possible for this odd man first to seduce a highly educated nation and then to nearly destroy it along with millions of non-Germans. Furthermore, no psychological explanation has yet satisfactorily explained Hitler's hatred of Jews, his Judeophobia.

As for attempts to diagnose Hitler using the current American Psychiatric system for diagnosing (DSM), the psychiatrist Fritz Redlich put it best when he said, "Using the DSM classification of personality diagnoses, not only in the case of Adolf Hitler, I often feel as if I were in a cheap clothing store: Nothing fits, and everything fits.” ([10], p. 332). In Redlich's own attempt at providing a diagnosis, he concluded by acknowledging a spiritual dimension—by diagnosing Hitler as a destructive and paranoid prophet.

When explaining Hitler, Redlich also placed a more modern emphasis on the role of transactions between Hitler and his environment, transactions not primarily in early childhood but later on, when Hitler's serious problems first appeared. He wrote, "A prophet needs followers... without them he would be a lone crank. To study the psychosocial transactions between Hitler and his followers is a crucial task, perhaps also more feasible than solving the riddle of the inner man in Hitler." ([10], p. 341). We will come back to this point when discussing when and how Hitler developed his pathological faith. Here, the main points are that Hitler does not fit neatly into a psychiatric category, and his problems cannot be derived simply from his childhood early experience. Finally, Hitler's problems are combinations of psychological and spiritual problems.

What about the historian's reference to Hitler's mind, his ideology, his worldview? Here, surely, we are on safer ground. Indeed we are, because Hitler left a long trail of evidence for deducing his 
thinking. The trouble is that without concepts referring to faith and spirituality, the analyses of Hitler's thinking, just as with the psychiatric analyses of Hitler's motives, have not captured Hitler's pathology. For example, Hugh Trevor-Roper writes brilliantly about Hitler's ideology, but, in the end, he treats it as a spirit-less blueprint for the materialist goal of getting the most for Germans. He wrote, "To him it was simply a question of more cakes for Germans and less for non-Germans" ([11], p. xxviii). Similarly, in his first biography of Hitler, Alan Bullock characterized Hitler as an opportunist whose ideology and sermonizing were nothing more than a propagandist's cunning theatrics designed to accumulate power for himself and the Nazi Party [12]. But Hitler's concerns were with much more than material success and power. Hitler's concerns were ultimate concerns, concerns about what is transcendent and concerns about his role as an instrument of Providence.

Most historians have understood this. Most have sensed that Hitler's problems were not just ideological problems but spiritual problems as well. However, lacking the words and concepts to articulate what they meant by spiritual, their characterization of the Hitler phenomenon as a spiritual phenomenon has been more a declaration about the limitations of historical research than it has been about any positive analysis of Hitler's spirituality. For example, without going into what he meant by spiritual, John Lukacs completed his own work on Hitler by saying, "(Hitler) had great talents given to him by God which he used for evil purposes, whence his responsibility: it is also...that his evil characteristics were spiritual.” ([4], p. 266).

\section{The Development of Hitler's Faith}

We come now to a critical point in the argument, the moment when we must make the case that Hitler had more than an ideology or belief system, that he had a faith. Simply put, the argument is that Hitler meets the criteria laid down by thoughtful scholars who have defined and explained the meaning of faith. Here, we rely especially on the writings of Paul Tillich and Wilfred Cantwell Smith. For Tillich, faith is the state of being "ultimately concerned" ([13], p. 4). For Smith, faith is,

"....a quality of the person, ... an orientation of the personality, to oneself, to one's neighbour, to the universe; a total response; a way of seeing whatever one sees and of handling whatever one handles; a capacity to live at a more than mundane level; to see, to feel, to act in terms of, a transcendent dimension." ([14], p. 12).

As such, faith cannot be observed directly or summarized in terms of an individual's beliefs. It can only be inferred from the quality of an individual's thoughts, judgments, and especially acts, from how an individual reacts to adversity, from the consistent way an individual addresses moral questions, from the pattern of an individual's relating to others. Faith, then, integrates an individual's personality and gives to a person's life the sense of being a life shaped by concern for what is transcendent, ultimate and sacred. A person of faith lives, then, on a different plane of existence from those without faith or with only an inconsistent or weak faith.

Given this definition of faith, can we say that Hitler had a faith? Certainly as an adolescent and young man, he did not. As Lukacs put it,

"There is a drastic change in both the content and the tone of (Hitler's) personal documents in 1919, but not before. The impression one receives of the younger Hitler is that of a loner, a dreamer, a German idealist- 
an impression that accords with the reminiscences of those who knew him during the war. In Hitler's extant notes, letters, and postcards to his friends, whether sent from the front or on leave, the expressions are often childlike, showing a doglike loyalty and deference to his officers and his country. With one exception...they are also apolitical." ([4], p. 59).

After 1919, everything about Hitler-his thinking and manner of speaking, his passion and persistence amidst tremendous adversity, his supreme confidence in himself and his cause — all pointed to one thing, namely, to his having a faith that was both powerful and terrible. From 1919 on, Hitler as a man of faith lived precisely as Tillich and Smith describe - at a different level and as if guided always by what he took to be ultimate, transcendent and sacred. After 1919, he was a man with a growing underlying spiritual purpose to save not only Germany but the world.

What happened around 1919 to transform Hitler from a man with no faith into a man whose faith defined his identity? First, there was Germany's defeat at the end of the First World War. That defeat proved devastating for most Germans, but for Hitler it was moreso. Before the war, Hitler's frustrated career as an artist and his near vagabond existence in Vienna came close to supporting what Redlich referred to as a "malignant identity diffusion" ([10], p. 306). The war years saved him by giving him a temporary and functional identity, but once the war ended, he was no further along in forming a lasting identity than he had been before the war. As Fest explained, when Hitler heard the news of Germany's defeat and cried, "I knew that everything was lost," he was expressing more a personal than a national sense of loss ([15], p. 79). So, the events following Germany's defeat proved crucial to Hitler's developing a faith. He was 'lost' and needed to be 'found', 're-born' and 'saved'. In short, he was ready for a conversion experience, for a new and (for him) saving faith.

Then, too, there was the near state of anarchy following Germany's defeat-the constant and bloody battles between right wing and leftist groups. Hitler became a member of a right-wing para-military group and received special training in "civic thinking", the object of which was to indoctrinate soldiers with historical, economic, and political theories that would foster nationalism and counter the communist revolution. For Hitler, this was a time that encouraged him to organize his thinking about broad issues having to do with economics, history, and nationalism.

However, by far the most important development at this time was Hitler's discovering his special talent for public speaking. The first recorded account of this talent came from Alexander von Muller who came across a gathering of students from one of the courses in "civic thinking". Fest records Muller's experience as follows:

He (Muller) found his way blocked by a group that 'stood fascinated around a man in their midst who was addressing them without pause and with growing passion in a guttural voice. I had the strange feeling that the man was feeding on the excitement which he himself had whipped up. I saw a pale, thin face beneath a drooping, unsoldierly strand of hair, with close-cropped mustache and strikingly large, light blue eyes coldly glistening with fanaticism.' ([15], p. 113).

This was the beginning of Hitler's amazing career as a public speaker and demagogue.

Hitler's talent for demagoguery provided an important mechanism for the development of his faith. Hitler systematized ideas from his days in Vienna, from his war days and from his courses in 'civic thinking' — not mainly for the purpose of organizing his thoughts but for the purpose of winning over his followers. More than anything else, it was Hitler's success as a public speaker before crowds that 
grew ever larger and ever more responsive that transformed his system of ideas into a faith. It was the crowds that confirmed his identity as a spiritual person, that spoke back to him with the overriding message that he was the man to lead them out of the wilderness, that he was their prophet.

All this was not immediately evident to Hitler. Nevertheless, even from the beginning, it must have occurred to him at some level that this incredible turnabout in his life, from being a miserable nobody to being a charismatic leader, all this must have meant that he had a much greater identity than could fit within a bourgeois role, that in some sense he was a prophet. Years later, before huge party rallies, Hitler would speak of the spiritual relationship between himself and his followers. At the 1937 party rally, he said, "That you found me long ago and that you believed in me has given your lives a new meaning, posed a new task. That I have found you is what has made my life and my struggle possible." ([15], p. 515). Therefore, in the case of Hitler, his prophetic faith developed as much through the reactions of his followers as through any revelations that arose in solitude.

Hitler's faith emerged, then, as a resolution to a personal identity crisis. The role of prophet not only filled a vacuum created by his having no role at the end of the war, it also satisfied a longstanding desire to be great. In 1905, at the age of sixteen, Hitler convinced his mother that he should quit school to prepare himself for a career as an artist. For two years, he lived mostly in his dreams of becoming a great artist. Those dreams were destroyed when the Viennese Academy of Art twice rejected him. Over a decade later, they were revived in a new form-when the militant crowds of Munich made him their fuhrer. The lesson here is an old one. Faith is not just about ideas and ideals. Faith can also be about the practical matter of finding a workable identity.

\section{The Content of Hitler's Faith}

"If I can accept a divine Commandment, it's this one: Thou shalt preserve the species." ([16] p. 116).

Having established when and how Hitler developed a faith, we have now to explain the content of that faith. It was, above all, a biological faith and a faith expressed by a particular image of Nature. Everything about Hitler's faith follows from this image — so we need to understand its significance. To do that, we need to say something about alternative images of Nature, images forming the backbone of positive patterns of faith-beginning with the faith expressed in primal religions.

Perhaps nowhere do we find Nature and spirituality so intertwined as in the primal religions. Unlike historical religions, primal religions mute distinctions between humans and Nature, between animate and inanimate. These are distinctions that primal peoples think of more as bridges than as barriers ([17], p 376). By thinking so, primal peoples experience themselves as being embedded in Nature, and for them, harmony with rather than dominion over Nature is their goal.

Why is this so for primal peoples? Why do primal peoples try to live in harmony with Nature rather than try to dominate Nature? Certainly, one answer is that being less technologically advanced, they have not been in a position to dominate. However, an additional answer is that primal peoples accept Nature as being nurturing. Primal religions are called "primal" because they are the original religions. They predate historical religions in time. However, they could also be called primal because their image of the Nature-human relationship is similar to that of the primal relationship between parent and child. As Huston Smith puts it, 
"Primal peoples are ... embedded in a single cosmos, which sustains them like a living womb. Because they assume it exists to nurture them, they have no disposition to challenge it, defy it, refashion it, or escape from it." ([17], p. 377)

From such an image, we see how primal peoples have thrived - thrived not so much in a material sense as in a moral and spiritual sense. In feeling nurtured, primal peoples can nurture. In connecting with Nature, they can connect with each other. In short, their image of Nature fosters and sustains core spiritual values.

Hitler, too, made no sharp distinction between humans and Nature. For Hitler, we are all simply creatures. However, being a creature in Nature meant, for Hitler, the opposite of living in harmony because, for Hitler, Nature was anything but nurturing. Trevor-Roper described Hitler's view of Nature best when he said:

"(Hitler) had views indeed of Nature and often spoke of his "communion" with it, but it was a hideous Nature, the devouring Nature whose cruelty justified his own; not a sociable pagan Nature of nymph-haunted woods and populated streams, but a romantic Wagnerian Nature of horrid Alps in whose intoxicating solitude he could best hatch his own equally violent and implacable interventions.” ([11], p. xxviii).

Throughout his speeches, his table talk, and Mein Kampf, Hitler made clear that Nature is cruel, not nurturing. In Mein Kampf, he wrote (or rather dictated):

"In the struggle for daily bread all those who are weak and sickly or less determined succumb, while the struggle of the males for the female grants the right or opportunity to propagate only to the healthiest. And struggle is always a means for improving a species' health and power of resistance and, therefore, a cause of its higher development." ([18], p. 285).

Despite superficial similarities, then, Hitler's faith has little in common with the faith of primal peoples. Furthermore, there is nothing in Hitler's image of Nature to foster and sustain what we ordinarily take to be moral and spiritual values. For Hitler, throughout the grim and gruesome drama of constant struggle, "Nature looks on calmly, with satisfaction, in fact." ([18], p. 285).

What about the historical religions and their images of Nature? How do they compare to Hitler's image? With the exception of Buddhism, the main issue for historical religions has been where humans fit between Nature and God. As Gustafson puts it:

"Somewhere between God and the world of Nature is an area large enough for several positions, ranging from humans being despots over Nature because God is so transcendent, to having dominion over Nature while still being dependent on it, to being a steward of the Divine in cooperation with Nature, to being subordinate to Nature because Nature is God." ([19], p. 78).

Gustafson and others show that within the theistic religions there has been tremendous variety with respect to images of the human-Nature relationship. However, historically, the predominant image has been the one that has humans having dominion over Nature.

With this image of dominion over Nature, followers of the historical religions have often exploited Nature. However, within the historical religions there have always been representatives, such as John Muir and Jane Goodall, pressuring humans to act responsibly - to become stewards looking after God's creation or to become enlightened beings who are compassionate for all. Therefore, while being 
embedded in a nurturing Nature is central for the primal religions, being responsible for Nature is central for the historical religions. As such, historical religions' images of the human-Nature relationship have the potential to support core moral and spiritual values having to do with justice and care.

How does Hitler's image of Nature compare to that of the historical religions? Since Hitler conflated creature and creation, he did not view humans as having dominion over Nature. In Mein Kampf, he said, “...man does not dominate Nature...” (p. 287), and much later, in his table-talk, he said, "It is senseless to encourage man in the idea that he's king of creation." (p. 71). However, in Hitler's image of Nature, there is nothing to suggest that humans are responsible for Nature. In fact, in his image, humans dominate Nature by being smarter than other creatures. Hitler's image of Nature and the human-Nature relationship provides, then, no support for being responsible in general-except if one adopts his specious argument that following the law of 'claw and fang' is being responsible.

We come now to a third and final comparison of Hitler's image of Nature with other images, namely, those images presented in recent discussions about science, religion, and Nature. One of the most positive developments in post-modern society has been the development of a healthy mistrust of science; a recognition that science and technology can diminish as well as enhance our quality of life. Perhaps nowhere is this mistrust more apparent than in discussions about ecological crises. As Stephen Kellert and Timothy Farnham put it:

"For both scientists and the spiritually and religiously inclined, the recognition grows that in our abuse of the earth we diminish our moral as well as our material condition. This mutual realization forges an understanding of the link between an environmentally degraded planet and a spiritually depauperate humanity. Conservationists, ever more cognizant of this connection, have increasingly acknowledged that both scientific and spiritual understandings are necessary in achieving an ethical sensibility capable of confronting the global crisis of pervasive environmental pollution, resource depletion, atmospheric degradation, and enormous biodiversity loss.” ([20], p. xiii).

In these more recent discussions about science, Nature, and religion, a new focus has emerged in thinking about Nature, a focus on aesthetics. These newer images of Nature and the human-Nature connection now emphasize the beauty of Nature and its workings. Furthermore, this spiritual-aesthetic focus has led not to a rejection of science but to a rationale for doing science, for using science to reveal the beauty of Nature. Through science and understanding how Nature works, we can experience religious feelings of wonder, awe and reverence for Nature-what the biologist Ursula Goodenough refers to as "religious naturalism" (Goodenough, [21], p. 167). In helping us know Nature's complex workings, then, we come to respect Nature, and in respecting Nature, we can better live according to a wider ethic of respect.

In comparison to religious naturalism, Hitler's image of Nature does little to foster respect, for, as Trevor Roper pointed out, Hitler's Nature was "hideous". There is nothing aesthetic or beautiful in Hitler's image, nor, certainly, is there a deep and accurate understanding of Nature's workings. So much then, for Hitler's image of Nature and its relation to alternative, positive images. We need now to turn to other images making up his faith.

The content of all patterns of faith include multiple core images that collectively provide an understanding of what it means to be fully human and that collectively support an ethic for living. The same is true of Hitler's faith. However, in the case of Hitler, it was his image of Nature that shaped, 
even determined the other images. For example, his image of divinity was that of a vague, impersonal force whose sole purpose was to set Nature's laws in motion. In a similar vein, his image of the "new man" who was to emerge from the Nazi revolution was that of a beast. To raise such a man, Hitler said:

"My pedagogy is hard. The weak must be hammered away. In my castle of the Teutonic Order a youth will grow up before which the world will tremble. I want a violent, domineering, undismayed, cruel youth. Youth must be all that. It must bear pain. There must be nothing weak and gentle about it. The free, splendid beast of prey must once more flash from its eyes." ([15], p. 233).

As for his image of the ideal woman, here too we find his image of Nature at work. Fest described the Nazi ideal woman as follows:

"... a blonde apotheosis beneath hair tied in a bun or plaited in a diadem; of the heavy-hipped, athletic woman in a long full skirt, wearing flat heels and freed from the prohibited stays, a figure lacking all intimacy and looking, for all its stylized naturalness, strikingly unnatural and radiating a discouraging pseudo-rustic jollity. In her every movement, this woman seemed actually conscious of her 'duty to the blood' and of carrying within her the 'necessary self-control in the interests of service to the race'." ([22], p. 270).

And from Hitler's table talk:

"A girl's object is, or should be, to get married. Rather than to die an old maid, it's better for her to have a child without more ado! Nature doesn't care the least bit whether, as a preliminary, the people concerned have paid a visit to the registrar. Nature wants a woman to be fertile.” ([16], p. 75).

As for his image of the individual, male or female, once again, we see his image of Nature at work, especially in defining the individual's worth and function. From his table-Talk:

"The life of the individual must not be set at too high a price. If the individual were important in the eyes of Nature, Nature would take care to preserve him.” ([16], p. 116).

Hitler's image of the ideal individual is someone willing to subordinate his own needs and wishes to the needs of the community. He wrote:

"It is essential that the individual should slowly come to realize that his own ego is unimportant when compared with the existence of the whole people." ([23] p. 142).

and,

"The greater the readiness to subordinate purely personal interests, the higher rises the ability to establish comprehensive communities. This self-sacrificing will to give one's personal labor and if necessary one's life for others is most strongly developed in the Aryan. The Aryan is not greatest in his mental abilities as such, but in the extent of his willingness to put all his abilities in the service of the community." ([18], p. 297).

Just as a biologist might view the death of a sickly member of a herd of elk as noteworthy only for leaving more food for the herd, so too Hitler viewed many sickly individuals as "life unworthy of life" because they diminished the community's health and energy.

Hitler's image of community was, then, not that of the just and caring community that defines the ideal for positive faith. It was, rather, a 'blood' community. In Fest's words: 
“(Hitler's) sincerest and most solemn thought, ... was this: to gather again the Aryan blood that had wasted itself on all the seductive Klingsor gardens of this world and to guard the precious grail for all time in the future, thus becoming invulnerable and master of the world. All the calculations of power tactics and all cynicism stopped short of this vision.” ([15], p. 533).

This image of a community based on race or 'blood' makes clear that Hitler was not the supernationalist he is often characterized to be. Rather, he was a super-racist. It also makes clear that his hatred for democracy stems not so much from a political philosophy as it does from his image of Nature. In one of his speeches, he declared:

"National Socialism takes as the starting point of its view and its decisions neither the individual nor humanity. It puts consciously into the central point of its whole thinking the Volk. This Volk is for it a blood-conditioned entity in which it sees the God-willed building-stone of human society. The individual is transitory, the Volk is permanent.” ([23], p. 142).

In sum, Hitler's image of community went beyond nationalism and his concern for the German State. Hitler's image of community reflected his Nature-based faith and his understanding of Nature's laws as having to do with race.

Hitler's image of community was also that of a non-democratic community organized according to the Fuhrer principle whereby the lines of authority all led to the top, to Hitler. Hitler believed that democracies relieved leaders of responsibility whereas dictatorships made leadership accountable.

In his own case, he felt he was more than up to the task; he felt he was a leader that comes along once in a millennium. In fact, few politicians have had a more inflated sense of worth than Hitler had of himself. However, it wasn't only his skills and mental powers that gave him his inflated sense of worth and that defined the spiritual dimension in his self-image. It was also his image of himself as being an instrument of Providence. His self-image as an instrument of Providence became, then, another core image defining his faith.

This self-image derived from Hitler seeing himself as having discovered the key to history. What was that key? Once again, it had to do with Nature and biology. Rome had built a great empire, and at its height, Rome was a model community for Hitler. But why, he asked, had Rome declined? Why had the glory of Rome been replaced by the Dark Ages? The answer was race - the mixing of blood that led to the adoption of poisonous democratic ideologies which, in turn, supported the weak and weakened the strong. In "discovering" race to be the key to history, Hitler came to see the world of his day as threatened on all sides by poisonous ideologies propagated by inferior races. He warned:

“...this planet once moved through the ether for millions of years without human beings and it can do so again some day if men forget that they owe their higher existence...to the knowledge and ruthless application of Nature's stern and rigid laws." ([18], p. 288).

His mission, then, was no less than that of turning this worldwide decline around and saving the world from regressing beyond saving.

This brings us to the last of Hitler's core faith images, his strange and terrible image of "The Eternal Jew". Of all the images constituting Hitler's faith, Hitler's image of Jews is the most strange and unfathomable. Historians have, in fact, given up the search for ultimate explanations of Hitler's Judeophobia. Fest wrote, "We can probably no longer plumb the real cause of this ever-growing hatred 
(of Jews) which lasted literally to the last hour of Hitler's life." ([15] p. 39). Lukacs followed with "The true motives-or, in other words, the real sources-of Hitler's Judeophobia are not ascertainable." ([4], p. 187). However, even if we cannot adequately explain the sources of Hitler's image of Jews, we can at least explain how this image functioned to complete his pattern of faith. That it belongs as a cornerstone in his faith is without question, because time and again he made clear that solving "The Jewish Problem" was his spiritual mission. At the very end of his life, with the destruction of Germany happening all around him, he announced with pride that at least he had lanced the Jewish abscess.

How should we explain the function of Hitler's image of Jews in his pattern of faith? One way might be to look at the origins of his anti-Semitism, where he got his ideas, and how like-minded comrades reinforced those ideas. However, this approach treats Hitler's Judeophobia too much like a theory. For Hitler, it was a theory-as indicated by his endless monologues about the destructive influence of Jews on the course of history. However, the theory is so absurd, so patently false that we should treat it as something different than a theory.

An alternative is to treat Hitler's image of Jews as a symbol, a symbol of the devil, evil, and all that is opposite to what he considered to be central to his faith. With such an approach, Hitler's image of Jews functions to clarify his faith. Seeing his image this way suggests that Hitler was following Martin Luther's suggestion, "No devil, no God". What Luther meant was that to understand God, one needs to understand the opposite of God. Transcendence is a correlative concept.

Once we see Hitler's image of Jews as his faith statement about what is not transcendent, about what runs counter to transcendence, then we can better understand his hatred for Jews. In hating Jews, he was hating that which he took to challenge his faith. While his own faith promoted the aristocratic principle, Jews promoted the democratic principle. While his own faith promoted a radical kind of nationalism designed to foster the "herd instinct" and wars leading to a survival of the fittest, Jews promoted international cooperation and pacifism. While his own faith promoted culling the national litter by eliminating the weakest and most infirmed, Jews promoted an egalitarian ethic that protected the weak and infirmed.

That Hitler's image of Jews served as a faith symbol of all that he found anti-spiritual is confirmed by the fact that in his later years he began to attack all opposition to his faith as deriving from the influence of Jews. For Hitler, communism was an obvious creation of the Jews - but so too was Christianity. It wasn't Jesus who defined Christianity, for Jesus was the likely offspring of a Roman centurion. Furthermore, for Hitler, Jesus was the angry Jesus throwing out Jewish moneylenders from the Temple, not the compassionate Jesus sharing his beatitudes in the Sermon on the Mount. For Hitler, Jesus was not the source of Christianity's poisonous ideology. Rather, it was the Jew, St. Paul, who gave Christianity its corrupting egalitarian ethic, the ethic that led to Rome's downfall. Similarly, behind Roosevelt and America's attacks on Nazism was the powerful influence of American Jews. Hitler's image of Jews was, then, central for helping define what his own faith was not.

Of course, this faith interpretation of the meaning and function of Hitler's image of Jews does not fully explain that image. Additional, clinical interpretations are needed. Hitler projected many of his own awful character traits onto Jews. Similarly, his sexual references to Jews raping, and defiling reveal his own conflicts around sex. However, none of these clinical interpretations refute the interpretation that Hitler's image of Jews helped to define his faith. 
These, then, are the core images defining Hitler's faith - the images of a cold, indifferent deity, a Nature invested in fostering violence, a community defined by racial purity, men and women defined by their basic instincts to dominate and propagate, and a self-image as prophet without doubt or humility Anyone confronting these images for the first time is likely to be repulsed. These images, then, do not need analysis for one to conclude the images are corrupt and that they collectively define Hitler's faith as pathological. However, if we are to use the case of Hitler to better understand spiritual pathology in general, analysis is needed.

\section{Understanding Spiritual Pathology}

In order to understand spiritual pathology, we must adopt an approach that provides the necessary criteria and categories for describing and evaluating it. There are several approaches to choose fromeach with its strengths and constraints.

A first approach is to follow the theologian's lead and to treat spiritual pathology as idolatrous spirituality. This is the approach taken by Tillich. For Tillich, idolatrous faith is faith in the conditional or faith in that which is not ultimate. A favorite example of Tillich's is faith in one's nation, and in his writing about this kind of idolatry, it was clear he had Nazi Germany in mind. For Tillich, idolatrous faith is pathological not simply because it is faith in the non-ultimate, but also because it fails to deliver on its promise of personal happiness.

Nazism certainly has many of the ingredients of what Tillich took to be an idolatrous faith. But was Hitler's faith a faith in that which is not ultimate? Not at all. As previously indicated, it wasn't the German nation that concerned Hitler ultimately. Rather, it was the salvation of the world. What could be more unconditional and ultimate than concern for the salvation of the world? Idolatry, then, is not primarily what defines Hitler's spiritual pathology.

A second approach is to treat a faith such as Hitler's as symptomatic of mental illness, that is, to treat it as symptomatic spirituality. I have already discussed the limitations of taking a mental health approach to Hitler, but the limitations mentioned had mostly to do with limitations of evidence and our systems for diagnosing. One could argue that if we had more evidence and better systems we could more fully explain spiritual pathology as symptomatic spirituality.

The trouble with this approach is two-fold. First, while it may seem reasonable to expect that new evidence and better systems for diagnosing should allow us to reduce a faith such as Hitler's to mental illness, history suggests otherwise. Faith and mental illness are categories falling in different realms of meaning. Each has its function for understanding human nature. To reduce one to the other robs us of what each can contribute. The category of faith contributes much by capturing that which integrates the lives of many and that which explains extraordinary sustained effort and achievement. Also, it is possible for a positive and powerful faith to exist despite mental illness or perhaps even because of its influence. History provides many examples of great spiritual leaders drawing strength from their psychological problems. Out of years of depression marked by psychotic breaks with reality, George Fox, the founder of the Society of Friends, or Quakers, developed his strong positive faith and answer to his anguished question, "Who will speak to my condition?" Regardless of evidence and diagnostic systems, then, it is extremely difficult, perhaps impossible, to reduce spiritual pathology to mental illness. 
A third approach is to treat Hitler's faith as a mistaken ideology whose pathology lies in its being wrong, what we might label as fallacious spirituality. This was Sebastian Haffner's approach when he said,

"(Hitler) had virtually programmed his failure. The image of the world which he had made for himself and on which his program was based happened to be incorrect. A policy aligned to that image could no more reach its goal than can a traveler using an incorrect map." ([24], p. 76).

Others, too, have evaluated Hitler's faith as an incorrect theory of realty. For example, Richard Lerner focused on the misconceptions in Hitler's theory of biological determinism and how those misconceptions led to disastrous public policies [25].

That Hitler was wrong about a lot of things is obvious. But does his being wrong capture his pathology? Not really. After all, misconceptions are everywhere - and yet we do not react by calling all misconceptions pathological. Nor do we react by calling even dangerous misconceptions spiritual. Therefore, this approach emphasizing how wrong Hitler was about Nature and evolution misses something crucial about his spiritual pathology.

A fourth approach is to take a purely pragmatic or functional approach and treat Hitler's faith as an example of dysfunctional spirituality. Certainly the fact that Hitler's faith led to the murder of millions gives reason enough to call it dysfunctional.

However, there are good reasons for rejecting this functional approach as well. First, whether or not a faith is dysfunctional has to do with conditions independent of that faith. Two equally pathological patterns of faith can turn out quite differently with respect to how they function. Second, an obviously pathological faith can have short-term benefits that provide, at times, crucial support and the possibility for long-term growth and development. The case of Malcolm X illustrates both points.

Malcolm X's Black Muslim faith had much in common with Hitler's. As in the case of Hitler's faith, Malcolm X's faith rested on an absurd theory about race and on an image of "The White Man" as the devil that was analogous to Hitler's image of the "Eternal Jew" as the parasite. And yet, Malcolm X's faith empowered and freed him to develop himself into becoming a model for blacks to imitate and for whites to learn from. The example of Malcolm X also illustrates how even a pathological faith can serve as a transitional faith because of its short-term benefits. Malcolm X's Black Muslim faith replaced his negative, adolescent identity and rescued him from a life of crime. Once that happened, he was open to being converted to the positive faith of Islam.

Whether or not a pathological faith becomes a transitional faith depends on circumstances independent of the individual. What might have happened had Malcolm X suffered extreme injustice during the time he was a Black Muslim? What might have happened had he been jailed repeatedly, beaten by whites, or had a member of his family killed? If any or all of these had happened, may we assume that Malcolm X's pathological faith would have become a motive for destruction and selfdestruction, so that today we would be evaluating it as dysfunctional spirituality? The answer, most likely, is "Yes".

However, we need not go away from the case of Hitler to make this point about the limitations of a functional approach. Hitler's faith was not dysfunctional until the very end of his political years-at least not from the point of view of most Germans. It is hard for us to remember, let alone appreciate, that before 1939, most Germans adored Hitler. He was adored because, as Ian Kershaw explains, he 
was successful [26]. He was successful in recovering the territories lost at the end of the First World War. He was successful at developing Germany into a world power. And, most important, he was successful at leading an economic miracle. As Fest put it,

If Hitler had succumbed to an assassination or an accident at the end of 1938, few would hesitate to call him one of the greatest German statesmen, the consummator of Germany's history. The aggressive speeches and Mein Kampf, the anti-Semitism and the design for world dominion, would presumably have fallen into oblivion, dismissed as the man's youthful fantasies... ([15], p. 9).

In other words, for most of his political career, Hitler's pathological faith was not dysfunctional.

A fifth approach is to treat the pathology of Hitler's faith as structurally undeveloped spirituality. This approach has three main advantages. First, it reveals that faith is neither static nor simply a matter of content. Faith develops to the extent that it develops structurally, that is, to the extent that it takes into account alternative views (e.g., other patterns of faith), apparent contradictions (e.g., believing in a just God while also believing that bad things happen to good people), and the symbolic nature of religious-spiritual language and expression,- - to name just three of several structural criteria for evaluating faith's development. Second, a structural approach provides ways of evaluating a variety of faith patterns whose content differs markedly from one another-so that it is possible to compare and contrast patterns of faith within and between religious traditions and point out important similarities with respect to development and maturity. Third, it provides a way to understand spiritual pathology as arrested faith development or as faith development gone awry.

Hitler's faith does indeed have structural problems, beginning with the problem of dogmatism. Mature faith is de-centered faith, faith that recognizes that one's own will and point of view are not synonymous with God's will and point of view_or the will and point of view that one would take if one could comprehend everything. Reinhold Niebuhr took Lincoln's faith to be an example of mature faith precisely because it was de-centered. He wrote, Lincoln "...could be responsible in executing historic tasks without equating his interpretation of the task with the divine wisdom." ([27], p. 87).

In contrast to de-centered faith, Hitler's faith was egocentric to an extreme. Time and again in his late night monologues, Hitler showed an astounding ignorance of spiritual perspectives found among the religious and an equally astounding confidence in his own interpretations of just about everything. This was not mere ignorance. This was pathological egocentricity or narcissism.

There are, then, good reasons for adopting a structural approach to defining spiritual pathology — as seen in the case of Hitler. However, a structural approach has one major limitation, a limitation that prevents it from becoming a primary approach to evaluating spiritual pathology. A structural approach fails to distinguish between patterns of faith that share the same problems but that lead in opposite directions - one in the direction of doing good and the other in the direction of doing evil.

This last point is illustrated by an example drawn from Susan Kwilecki's interviews of mostly poor and poorly educated adults from the rural south in Georgia [28]. Kwilicki writes about 'Jack McCullers' receiving a divine command to purchase a head gasket for a Toyota, when he didn't own one or know anybody who did. Rather than call this immature or pathological, Kwilecki says, "What could be sillier than thinking that the ruler of the universe would waste time on such a message? What could be lovelier than thinking that the ruler of the universe is so intimate and playful?" [29]. Kwilecki 
found, then, something quite positive in McCullers' faith-by attending not to its immature structure but to its image of divinity.

This brings us to the primary approach adopted here for evaluating Hitler's faith and spiritual pathology in general. This approach focuses not on the ultimacy of a faith's concerns, nor on mental illness and misconceptions, nor on structural and functional problems. Rather, it focuses on a faith's core images and what values they seem to support. The approach can be used to simply describe. It need not evaluate. However, in cases such as Hitler, to describe without evaluating would be offensive. Simply describing Hitler's faith implies that it might be perfectly fine under certain conditions. Few today accept such an implication.

Using this approach, then, whether or not a faith is pathological depends first and foremost on whether or not its images are about values that support a moral life. From this perspective, whether it goes by the name of God, Nature, Nirvana or some other ultimate term, the object of our faith must be a term for what is Good-a perspective shared by Richard Wood and other moral philosophers and theologians [30]. The object of Hitler's faith was anything but good.

Hitler's faith was pathological because its images failed to support the moral life. Hitler and the Nazis did have a moral code - as the following quote from Himmler's Posen Castle speech clearly indicates:

"The brief sentence 'The Jews must be exterminated' is easy to pronounce, but the demands on those who have put it into practice are the hardest and the most difficult in the world....We, you see, were faced with the question 'What about the women and children?' And I decided... to find an unequivocal solution. For I did not think that I was justified in exterminating - meaning kill or order to have killed - the men, but to leave their children to grow up to take revenge on our sons and grandchildren. The hard decision had to be taken to have this people disappear from the face of the earth. For the organization, which had to carry out this order, it was the most difficult one we were ever given... I think I can say that it has been carried out without damaging the minds or spirits of our men and our leaders. The danger was great and ever present. For the difference between the two possibilities ... to become cruel and heartless and no longer to respect human life, or to become soft and succumb to weakness and nervous breakdowns... the way between Scylla and Charybdis is apparently narrow." ([31], p. 390).

While Hitler and Himmler disagreed on many issues, they did not disagree on issues of morality. They shared the same moral code and mission to be dispassionate about killing for the sake of preserving the nation and hope for mankind's progress. Their morality, was a different kind of morality, a morality that most, regardless of tradition, absolutely reject. Furthermore, their morality was rooted not primarily in faulty superegos and faulty reinforcement histories nor in co-constructions with others about what is good, but in problematic images of God, Nature, human nature, community and self.

Lest anyone think that problematic images are found only in pathological faith such as Hitler's, we need only remind ourselves that problematic images can be found almost everywhere. Barry Schwartz has discussed how some of today's most troubling problems can be explained as a playing out of the problematic images of human nature found in the disciplines of economics, evolutionary biology, and behavior theory [32].Indeed, to a large extent, Hitler's own faith images were simply exaggerations of images found in the respected disciplines and theories of his day-particularly in scientific racism and the political philosophies supporting colonialism.. Once again, evil can derive from the ordinary. 
But though evil and pathological faith derive from the ordinary and are exaggerations of the everyday, there is about them something qualitatively different from the ordinary. Just as water at 20 degrees fahrenheit is not simply 20 degrees cooler than water at 40 degrees fahrenheit, so too Hitler's faith and images are not simply so many degrees different from everyday faith and images. At some point, what is merely a faith that annoys and diminishes, transforms into a faith that destroys.

\section{Final Thoughts}

The word, evil, may distance some readers. It may sound like a throwback to an earlier, dogmatic, and less sophisticated time when good and evil were conceived narrowly in terms of local religions and local cultures. It may do this because, as Andrew Delbanco has pointed out, we live in a culture of irony where good and evil are felt to be relative to one's position in time and space [33].We are conditioned, then, to resist naming evil-although worldwide terrorism may yet break down the resistance. The problem with our resistance is that in failing to name evil, we distance ourselves from evil, and in distancing ourselves from evil, we become powerless to combat evil. We become like the reservists at Jozefow.

Our resistance is also due to our continuing to mistrust the notion and reality of faith itself - as being a childish illusion or poor substitute for science. If faith is a matter of having "good" images, by what criterion do we distinguish mature faith from childish faith in a fairy godmother? There is an answer. Mature faith is realistic faith that promotes a moral life. To align oneself with the Good is neither naïve nor childish. When after the death of his child, Rabbi Harold Kushner changed his image of God from that of an all-powerful but not so compassionate God to a totally compassionate but not all-powerful God, he did so not to soothe his troubled feelings and make the world unrealistically nice. He did so to adjust his image of God in the light of his new-found understanding of compassion [34]. Furthermore, his new understanding came not from his looking to the heavens but from his looking all around him - to those who did not know how to be compassionate and to those who did. Furthermore, for Kushner, a totally compassionate God was more than powerful enough because the only power that concerned him was the power to support a moral life. For Kushner, as for all those with positive patterns of faith, good faith is faith in the reality of Goodness and in its power to support us in doing good and opposing evil.

\section{References}

1. Browning, C.R. Ordinary Men: Reserve Police Battalion 101 and the Final Solution In Poland; Harper Perennial: New York, NY, USA, 1993.

2. Goldhagen, D.J. Hitler's Willing Executioners: Ordinary Germans and the Holocaust; Vintage Books: New York, NY, USA, 1996.

3. Storr, A. Feet of Clay: Saints, Sinners, and Madmen: A Study of Gurus; Free Press: New York, NY, USA, 1996.

4. Lukacs, J. The Hitler of History; Random House: New York, NY, USA, 1997.

5. Miller, A. For Your Own Good: Hidden Cruelty in Child-Rearing and the Roots of Violence; Farrar-Straus-Giroux: New York, NY, USA, 1989. 
6. Fromm, E. The Anatomy of Human Destructiveness; Rhinehart \& Winston: New York, NY, USA, 1973.

7. Stierlin, H. Adolf Hitler: A Family Perspective; Psychohistory Press: New York, NY, USA, 1976.

8. Erikson, E. Childhood and Society; W.W. Norton \& Co.: New York, NY, USA, 1950.

9. Binion, R. Hitler Among the Germans; Elsevier: New York, NY, USA, 1976.

10. Redlich, F. Hitler: Diagnosis of a Destructive Prophet; Oxford University Press: New York, NY, USA, 1999.

11. Trevor-Roper, H.R. The Mind of Adolf Hitler. In Hitler's Secret Conversations; Farrar, Straus, \& Young: New York, NY, USA, 1953.

12. Bullock, A. Hitler, A Study in Tyranny; Harper \& Rowe: New York, NY, USA, 1952.

13. Tillich, P. Dynamics of faith; Harper Brothers: New York, NY, USA, 1957.

14. Smith, W.C. Faith and Belief: The Difference between Them; Oneworld Publications: Oxford, UK, 1998.

15. Fest, J. Hitler; Harcourt Brace: New York, NY, USA, 1973.

16. Hitler, A. Hitler's Secret Conversations; Farrar, Straus, \& Young: New York, NY, USA, 1953.

17. Smith, H. World's Religions: A Guide to Our Wisdom Traditions; HarperCollins: New York, NY, USA, 1995.

18. Hitler, A. Mein Kampf; Houghton Miflin Co.: New York, NY, USA, 1971.

19. Gustafson, J.M. A Sense of the Divine: The Natural Environment From A Theocentric Perspective; The Pilgrim Press: Cleveland, OH, USA, 1994.

20. Kellert, S. Values, ethics, and spiritual and scientific relations to nature. In The Good in Nature and Humanity: Connecting Science, Religion, and Spirituality with the Natural World; Kellert, S., Farnham, T., Eds.; Island Press: Washington, DC, USA, 2002.

21. Goodenough, U. The Sacred Depths of Nature; Oxford University Press: New York, NY, USA, 1998.

22. Fest, J. The Face of the Third Reich: Protrait of the Nazi Leadership; Da Capo Press: New York, NY, USA, 1999.

23. Spielvogel, J. Hitler and Nazi Germany; Prentice Hal: Upper Saddle River, NJ, USA, 1996.

24. Haffner, S. The Meaning of Hitler; MacMillan Publishing Co.: New York, NY, USA,1979.

25. Lerner, R.M. Final Solutions: Biology, Prejudice, and Genocide; The Pennsylvania State University Press: University Park, PA, USA, 1992.

26. Kershaw, I. The 'Hitler Myth': Image and Reality in the Third Reich; Oxford University Press: New York, NY, USA, 1987.

27. Niebuhr, R. The Irony of American History; Scribner \& Sons: New York, NY, USA, 1952.

28. Kwilecki, S. Becoming Religious; Associated University Press: Cranbury, NJ, USA, 1999.

29. Kwilecki, S. Personal Communication. Radner University, Radner, VA, USA, 2006.

30. Wood, R. Ethics and the Good in Nature and Humanity. In The Good in Nature and Humanity: Connecting Science, Religion, and Spirituality with the Natural World; Farnham, S.K.T., Ed.; Island Press: Washington, DC, USA, 2002.

31. Sereny, G. Albert Speer: His Battle With Truth; Vintage Books: New York, NY, USA, 1995.

32. Schwartz, B. The Battle for Human Nature: Science, Morality and Modern Life; W.W.Norton \& Co.: New York, NY, USA, 1986. 
33. Delbanco, A. The Death of Satan: How Americans Have Lost the Sense of Evil; Farrar, Strauss, \& Giroux: New York, NY, USA, 1995.

34. Kushner, H. When Bad Things Happen to Good People; Avon: New York, NY, USA, 1981.

(C) 2012 by the author; licensee MDPI, Basel, Switzerland. This article is an open access article distributed under the terms and conditions of the Creative Commons Attribution license (http://creativecommons.org/licenses/by/3.0/). 